\title{
COMMODITIES AND TRANSACTIONS EXEMPT FROM CONSUMPTION TAXES
}

\author{
Grorge T. Frampton* and Numa L. Smith†
}

In a broad sense the phrase "exemption from consumption taxes" may be used to embrace those untaxed subject matters which fall outside the scope of the taxing statute. ${ }^{1}$ It will be used more narrowly here, however, to denote exceptions from a taxable class. Since Winter $v$. Barrett, ${ }^{2}$ when exemptions of sales of motor fuel otherwise taxed and sales made by agricultural producers were declared invalid under a particular constitutional provision of Illinois requiring state taxation to be "uniform as to the class on which it operates," the constitutionality of consumptiontax exemptions has never been seriously questioned. ${ }^{3}$

\section{General Sales and Use TAxes}

Because these exemptions bear the earmarks of subsidies, which must be made up from some other source, they can be justified, not by mere legislative fiat, but only on sound economic and social grounds. It is proposed to examine them accordingly, classifying them, for convenience of treatment, on the basis of their motivation. So categorized there are exemptions which (I) simplify administration of the statute; (2) mitigate regressive features of the tax; (3) obviate multiple taxation, either vertically or horizontally; or (4) arise from political or group pressure. Some of the exemptions, to be sure, resist such a classification. Many states, for example, exempt from their general sales and use taxes the sale of farm products by the farmer. Since the farmer is a powerful influence in most state legislatures, this exemption is certainly not unrelated to group or political pressure; from the standpoint of administrative convenience, moreover, it avoids the difficulty of col-

- A.B., 1938, LL.B., 194r, Duke University. Editor, Duke Bar Association Journal, I939-194I.

† A.B., r938, Furman University; LL.B., 1941, Duke University. Editor, Duke Bar Association Journal, 1939-194x.

${ }^{1}$ See Martin, The Social Aspects of Tax Exemption (1936) I83 Annals 48.

352 Ill. 44I, 186 N. E. I13 (I933).

${ }^{3}$ Nachman v. Tax Comm'r, 233 Ala. 628, I73 So. 25 (I937); Frazier v. Tax Comm., I3 Cal. App. (2d) 720, 57 P. (2d) I022 (1936); Jones v. Grady, I69 Md. I73, 80 Atl. 272 (1935); Notgrass Drug Co. v. State, I75 Miss. 358, 165 So. 884 (1936); Fox v. Frank, 52 Ohio App. 483, 3 N. E. (2d) 996 (1935). To the textual statement there must be entered one caveat concerning the situation in Illinois itself. Under the constitutional provision above quoted, Ill. Consr. art. 9, \$I, an exemption, to be valid, seemingly requires a statutory delimitation of the taxable class. Thus, the present movement in Illinois to exempt food will, if consummated, necessitate a new law which exacts the tax only on sales of tangible, nonesculent personal property. See (I940) 26 Bull. NAT. TAX Ass'N 88-89; (I94I) I9 TAXEs III.

'See also the classification by Shoup, Tax Exemption (1934) I4 ENcyc. Soc. Sciences 528. 
lecting a tax from thousands of small producers who have no records and who might yield less than the cost of administration.

\section{Administrative Expediency}

Some exemptions obviously increase administration burden and costs, since they necessitate a separation of non-taxable from taxable transactions. This fact alone might be enough to condemn particular exemptions, unless toleration of high costs and reduced administrative efficiency is assured by counter-balancing equities. On the other hand, administration costs which are disproportionate to the revenue raised from taxing a particular transaction, and administrative difficulty in levying the tax, might possibly justify the exemption of that transaction. The degree of importance of these factors as the raison d'etre of any exemption cannot be accurately ascertained; probably, they are rarely the sole motivation.

This concession to administrative expediency is perhaps best illustrated by "casual and isolated" sales, which are exempted by specific language in eight states," either by an excluding definition of "engaging in business" or of a "sale at retail," or by an outright exception. Were an effort made to tax, for instance, the sale by Jones of his household furniture to Smith, it is apparent that the result would be one of administrative confusion. The increase in the number of potential taxpayers would force the various revenue offices either to employ house-to-house canvassers or to rely wholly upon the taxpayer to report the sale.

The exemption itself raises a perplexing question of construction as to what constitutes a "casual and isolated" sale. The Kansas act, stating that an "isolated or occasional sale of tangible personal property ... by a person not engaged in such business does not constitute engaging in business, within the meaning of this act," is typical of the provisions effective in the various states. Pertinent litigation is sparse, but administrative rulings and the few cases which turn on this point indicate that the test of "engaging in business" is whether there is a "systematic recurrence and continuity" of such sales. ${ }^{6}$ Application of the test to antipodal situations is fairly easy, as is demonstrated by the Ohio case of State $v$. Zellner, ${ }^{7}$ in which the state supreme court refused to extend this exemption to sales of property which had been acquired by a loan company on foreclosure of chattel mortgages given as security, such sales exceeding $\$ 25,000$ annually. And, in Sioux Falls Motor Co. v. Welsh, arising under the South Dakota provision, the court of that state found that a new car dealer necessarily had to engage in the business of selling used cars, with the consequence that sales of the latter were not "casual and isolated."

5 Ark. Dig. Stat. (Pope, 1937) \$14069(b)2; ILI. Rev. Stat. (Bar Ass'n ed., 1939) c. 120, \$440; Kan. Gen. Stat. Ann. (Corrick, Supp. 1939) \$79-3602(k); Mich. Comp. Laws (Mason, Supp. 1940) $\$ 3663$-I (b); N. M. Stat. Ann. (Courtright, Supp. 1938) \$141-1703(g); Ohio Gen. Code Ann. (Page, 1937) \$5546-2; S. D. Code (1939) \$57.310I(6); Wash. Rev. StAT. ANN. (Remington, Supp. 1940) \$8370-r9(a); W. VA. Code AnN. (Michie \& Sublett, I937) \$999(2)5. Ohro Gen. Code ANn. (Page, I937) $\$ 5546-2(9)$ also exempts sales incidental to professional services.

${ }^{-}$See, for example, Kan. Reg. and Rulings (x940) art. 9 (b).

${ }^{7}{ }_{133}$ Ohio St. 263,13 N. E. (2d) 235 (1938). ${ }^{8} 65$ S. D. 68,270 N. W. 852 (1936). 
But the cases arising in the twilight zone are not so easily disposed of, for ascertaining whether such sales are made often enough to be considered a part of the vendor's business cannot be done by a rule of thumb. It would seem, however, that in so far as the exemption is rested upon administrative convenience, there is little justification in labeling as "casual and isolated" a sale which is shown on the records of a vendor registered under the sales tax act. Significantly, several states apparently confine the exemption to vendors who are not engaged in the business of selling. Ohio, for example, exempts a "casual and isolated sale by a vendor not engaged in the business of selling tangible personal property." A literal construction of such a clause would rule out a sale by a vendor whose business is selling, even though the article sold were unrelated to his regular business; it is probable, however, that a more liberal construction will be followed and that sales unrelated to the vendor's ordinary business of selling will be exempt. ${ }^{10}$ Since this interpretation will itself raise additional problems of what is an unrelated sale, there might be further reason for thinking a strict construction desirable.

Another concession to administrative expediency is apparent in the exemption of sales of farm products and livestock when made by the producer. Found in no less than seven states, ${ }^{11}$ this exemption is, of course, to a large extent also a recognition of the power of the agricultural blocs in the various state legislatures. But again there is the difficulty of enforcing the tax against vendors who keep no records and whose sales to consumers are small. Aside from the inherent trouble in deciding what are farm products, ${ }^{12}$ this exemption disturbs the equitable principle of uniformity, since it discriminates against those vendors who sell produce which they have purchased. Unquestionably, the tax can be more easily collected from retailers and curb market operators, but it is doubtful that either the fact of production or administrative expediency is a sufficient basis for a discriminatory subsidy of direct marketing. A strict construction, either by a narrow interpretation of farm products or by emphasis on the reasons underlying the exemption, would seem desirable. The latter approach is well illustrated by Curry $v$. Reeves, ${ }^{13}$ in which the Alabama supreme court refused to extend the exemption to a farmer-retailer who sold in his store baby chicks hatched from eggs collected on his farm. The court stated that the exemption was given to help the farmer as a farmer and that to grant it here would be to help the farmer in his position as a merchant. It may also be noted

\footnotetext{
- The New Mexico statute similarly defines an isolated sale as one made by a person who does not "hold himself out as engaged in business." N. M. STAT. ANN. (Courtright, Supp. 1938) $\$ x_{4} x_{-1703}(g)$.

${ }^{10}$ Carnicom v. Tax Comm., 5 Ohio O. 348 (Com. Pl. I936).

${ }^{11}$ Ala. Gen. Acts 1939, act No. I8, \$5(f); Ark. Dig. Stat. (Pope, 1937) \$14071; Miss. Code Ann. (Supp. 1938) \$2328; N. M. Stat. Ann. (Courtright, Supp. 1938) §I4I-IjI6; N. C. Code Ann. (Michic, I939) $\$ 7880$ (156)f; Okla. Laws 1937 , c. 66. art. Ix, $\$ 6(f)$; Wyo. Laws 1937, c. II8, $\$ 4$ (c) (use tax exemption). See Buehler, General Sales Taxation (I932) I54; Jacoby, Retail SaIes Taxation (I938) ir6; Sates Taxes: Generat, Selective, and Retail (Nat. Ind. Conf. Bd., r932) I6-r8; Note (I934) 47 HaRv. L. Rev. 860, 864.

13 Seo Haig and Shoup, The Sales Tax in the American States (1934) 88.

${ }^{13}$ I95 So. 428 (Ala. 1940). That a cotton ginner cannot claim an exemption as a producer of farm products, see Frazier v. Stone, I7I Miss. 56, 156 So. 596 (1934).
} 
that the administrative reason for the exemption is satisfied by this set of facts, as no difficulty in collecting the tax from the farmer-merchant would be involved.

Finally, an exemption based wholly on administrative convenience is that allowing tax free the use of property up to a certain amount and for a stipulated period. Although such exemption appears in the statutes of only five states, ${ }^{14}$ it is, from an administrative standpoint, impossible to exact the tax to the last penny, even in the absence of an exempt minimum, since the cost of doing so would be prohibitive. The most that an all-out effort to enforce the use tax could bring would be a plethora of petty tax evasion. As one writer has pointed out, this exemption is a tacit admission that it is expedient to collect the tax only from the larger taxpayers. ${ }^{15}$ In a way, therefore, this exemption is a mitigation of the regressive feature of the tax, although its motivation is decidedly not that. Of the states with the retail sales tax, only Michigan grants a flat-sum exemption. ${ }^{16}$ Rather than a concession to administrative expediency, this exemption seems to be an effort to help the retailer defray his share of the costs of the tax. ${ }^{17}$

\section{Mitigation}

Few, if any, economists defend the justness of sales taxes. ${ }^{18}$ A fixed tax of one cent on a ten-cent purchase, they point out, is unrelated to the consumer's ability to pay that cent; nor are wealthy consumers taxed a higher percentage of their outlay simply because they pay more taxes through increased purchases. Exemptions of non-luxuries or essentials in many states may be understood in the light of this criticism of consumption taxes, although other motives may have impelled their enactment. Items placed in the category of essentials or necessaries by legislative declaration include medicine ${ }^{10}$ and students' textbooks. ${ }^{20}$ No doubt North Carolina's exemption of the sale of coffins ${ }^{21}$ was inserted to remove the sting from the argument that the consumer is taxed from the cradle to the grave.

14 Kan. Gen. Stat. Ann. (Corrick, Supp. I939) \$79-3704; Mich. Comp. Laws (Mason, Supp. 1940) $\$ 3663-44$; Miss. Code Ans. (Supp. 1938) \$2358; N. D. Laws 1939, c. 241, \$3; Okla. Laws 1939, c. 66, art. $12, \S 5$.

${ }^{15} \mathrm{JACOBY}$, op. cit. supra note $\mathrm{Ir}$, at 154 .

${ }^{16}$ Mich. Comp. Laws (Mason, Supp. 1940) $\$ 3663-4$.

${ }^{17}$ See Huston and Berryman, Collection and Enforcement of State Consumption Excise Taxes, supra this issue, at p. 518, n. 37 .

${ }^{18}$ BueHLER, at 245-246; JACOBY, at 85, both op. cit. stipra note 11 ; Hate AND Shoup, op. cit. supra note 12, at 8. But contrast Pierce, The Place of Consumption Excises in the Tax System, supra this issue.

${ }_{10}$ N. C. CODE ANN. (Michie, 1939) $\$ 7880(156) \mathrm{f}(\mathrm{k})$.

${ }^{20} \mathrm{Ala}$. Gen. Acts 1939, act No. I8, §5(d); Iowa CODE (Reichmann, 1939) $\$ 6943.076(4)$, as interpreted by Rep. Atry. Gen. (Iowa 1938) 6ox; Mrch. Comp. Laws (Mason, Supp. 1940) \$3663-4a(d); Miss, Cope ANN. (Supp. 1938) §2328(I); N. C. Code ANN. (Michie, 1939) \$7880 (156)f(g); N. D. Laws 1937, c. 249, \$3(c); N. M. Stats. ANN. (Courtwright, Supp. 1938) \$141-1716(c); W. VA. Code ANn. (Michic \& Sublett, I937) $\$ 999(9) 3$. For judicial comment on the desirability of the schoolbook cxemption, sce Notgrass Drug Co. v. State, supra note 3 , at 366 , I65 So. at 885 . North Carolina also exempts the sales of Holy Bibles. N. C. Pub. Laws I94r, c. $158, \$ 406(\mathrm{~g})$.

${ }^{31}$ N. C. CODE ANN. (Michie, I939) $\$ 7880(156) \mathrm{f}(0)$. In the absence of an express exemption, the sale of a casket is a taxable sale of tangible personal property and is not a part of a contract for service. Kistner v. Iowa State Board, 225 Iowa 404,280 N. W. 587 (1938). Neither is it a sale of realty or a sale incidental to a professional service. Ahern v. Nudelman, 374 Ill. 237,29 N. E. (2d) 268 (1940). 
But by far the most important of this type of exemption is that favoring food or food products. Already enacted in seven states, ${ }^{22}$ it is currently proposed in at least six more. ${ }^{23}$ Some states confine the exemption to milk ${ }^{24}$ or to sales of luncheons to school children. ${ }^{25}$ Others have attempted to extend the exemption to a fairly large list of specific staples, ${ }^{26}$ but the effect of this enumeration is to enlarge problems of administration and to encourage petty litigation over definitions. Thus, in Alabama it was necessary to go to court to determine that flour included self-rising flour; ${ }^{27}$ in Arkansas, to determine that butterfats included whole milk. ${ }^{28}$ Most states, therefore, exclude all food products purchased for human consumption, frequently excepting from that definition candies and confectionaries, vitamin medicines, soft drinks and sodas, and food prepared and served on the premises. ${ }^{29}$ These exceptions of luxurious food purchases also give rise to administrative difficulty, especially in distinguishing between confectionaries and ordinary sugar products. A Hershey bar has been found by the United States Supreme Court to be a candy, and not a food, for the purposes of a federal statute taxing candy $;^{30}$ but the Ohio supreme court has found a chocolate peppermint to be a food, and not a candy or confectionary excepted from the food exemption. ${ }^{31}$ Further opportunity for judicial extension or contraction of the scope of the exemption is afforded in the construction of the phrase "for human consumption." The court in Kirk v. Johnson ${ }^{32}$ narrowly construed that phrase to mean immediate human consumption, rendering taxable the sale of a dairy cow for milking and ultimate slaughtering and consumption.

A food exemption drastically reduces sales tax receipts. If the North Carolina experience in the fiscal year 1939-1940 be typical, the tax receipts from sales by gro-

${ }^{22}$ Ala. Gen. Acts I939, acts No. I8, §5(0), and 155; CaL. GeN. LAws (Deering, Supp. I939) act 8493, §2(e), §5(e); La. Laws I940, act II5, \$4; Mich. CoMp. LAws (Mason, Supp. I940) \$3663-4a(d); N. C. Pub. Laws I941, c. 158, \$6(c); Oho Gen. Code ANN. (Page, 1937) \$5546-2(2) and (II-a); Okla. Laws I939, c. 66, $\$ 6(i)$.

${ }^{23}$ Ark. H. B. No. 426 ; Ind. H. B. No. 418 ; Ore. H. B. No. 304 ; Wash. H. B. No. 167 , S. B. No. 23; W. Va. H. B. No. 22 , S. B. No. 89 , all $x 94$ r. Wis. S. J. Res. No. 9, I94x, proposes a constitutional amendment to exempt food, clothing, fuel, or "other necessary of life."

${ }^{34}$ Ala. Gen. Acts 1939, act No. 155; La. Laws I940, act I15, §4.

${ }^{25}$ Ala. Gen. Acts 1939, act No. 18, \$5(o); CaL. GeN. Laws (Deering, Supp. I939) act 8493, \$2(c); Mich. Comp. Laws (Mason, Supp. 1940) \$3663-4a(d); Oho Gen. Code AnN. (Page, 1937) \$5546-2 (Ir-a); Okla. Laws 1939 , c. $66, \S 6$ (i). See also Ark. H. B. No. 426, I 941 .

${ }^{20}$ Until recently North Carolina exempted flour, meal, meat, lard, milk, molasses, salt, sugar, coffee, bread, and rolls. N. C. Pub. Laws 1939 , c. $158, \$ 406(i)$. Until recently Washington exempted fresh sweet milk, raw fruit, butter, eggs, cheese, and bread. Wash. Law's 1935, c. 180, tit. 3, §rg. W. Va. S. B. No. 89, r941, would exempt sales of bread, milk, eggs, flour, and butter.

${ }^{27}$ Holt v. Long, 234 Ala. 369 , I74 So. 759 (I937). At that time Alabama exempted sweet milk, buttermilk, cornmeal, flour, dry salt sides, salt fat backs, plates, bellies, sugar, and coffee. Ala. Loc. and Gen. Laws $1936-7$, act No. 125, $\$ 4(\mathrm{j})$.

${ }^{28}$ Wiseman v. Affolter, I92 Ark. 509, 92 S. W. (2d) 388 (1936). At that time Arkansas exempted "all foods necessary to life," specifically defined as flour, meat, lard, sugar, soda, baking powder, salt, meal, butterfats, eggs, and medicines. Ark. Laws I935, act 233, $\$ 15(2)$.

${ }^{30}$ Cal. Gen. Laws (Deering, Supp. I939) act 8493, $\$ 5(\mathrm{e})$; N. C. Pub. Laws 1941, c. 158, \$6(c); Ohio Gen. Code Ans. (Page, I937) $\$ 5546-2(2)$. See, on this point, Haig aNd Shoup, op. cit. supra note 12 , at $653-654$.

${ }^{30}$ MrCaughn v. Hershey Co., 283 U. S. 488 (I93I).

${ }^{31}$ Andrews v. Tax Comm., 135 Ohio St. 374, 2I N. E. (2d) 106 (1939).

${ }^{32} 37$ Cal. A. (2d) 224, 99 P. (2d) 279 (1940). 
cery, meat, fruit, and vegetable markets alone would exceed in amount the entire automotive, apparel, or furniture groups and would represent roughly ten per cent of the entire proceeds from sales and use taxation. ${ }^{33}$ Under the North Carolina law as it then stood the exemptions of specific food items withdrew about two-fifths of all food sales from taxation. A few weeks after the inauguration of a new governor, who had campaigned on a blanket food exemption plank, such an exemption was legislatively approved, with an anticipated loss in revenue estimated at $\$ 1,500,000$.

This effort to mitigate the regressive features of the tax, although justified because it surely "alleviates the living costs of the masses," 34 is at the same time an effort to undo what the tax itself purports to do: measure consumer outlay. The very existence of these exemptions thus testifies to the unsoundness of such a policy. And their presence is little more than a patchwork remedy. The purchase of an article, in the first place, is often to be termed necessitous or luxurious depending not so much upon the nature of the article as upon the relationship of the purchase to the consumer's needs. ${ }^{35}$ When a wealthy man purchases 50 pairs of shoes, food for a lavish banquet, and water for his lawn and gardens, the burden of taxation is eased upon him as well as upon his poorer neighbor, with a consequent loss of revenue which is a problem for both citizen-taxpayers. No state, in the second place, has attempted more than a sporadic exemption of this or that necessity; the alternative of working out a fairly consistent blanket of exemptions of necessitous articles would pose the problem of legislative demarcation of the limits of "necessities" and "luxuries" in a society with a fixed or changing standard of living.

\section{Multiple Taxation}

Multiple taxation, as it relates to consumption taxes, may result from placing several different taxes on the sale of the finished product (horizontal), or from taxing the commodity at various stages of its assimilation (vertical). In most instances the states have assiduously tried to avoid multiple taxation by express exemptions and by denominating certain transactions as wholesale, which are thus put outside the scope of the retail acts.

In general, exemptions of the horizontal type are economically justified, since they prevent discrimination against expenditures on commodities which are specially taxed, usually at a rate higher than that of the general consumption taxes. Included in this group are the exemptions of alcoholic beverages, ${ }^{30}$ cigarettes and

\footnotetext{
${ }^{33}$ The fruit-vegetable-grocery-meat tax proceeds in North Carolina in the fiscal year r939-40 werc $\$ I, 7 \times 1,392.60$. By comparison the automotive group yielded $\$ 1,610,986.38$; the apparel group, $\$ 990,679.89$; and the furniture group, $\$ 8$ ro,945.97. The total yield was $\$ 1 \mathrm{r}, 377,980.37$. N. C. Dept. Rev., Analysis of Sales and Use Tax Collections for Fiscal Year July I, 1939 through fune 30, 1940 (mimeographed). ${ }^{34}$ BUEHI.ER, Op. cit. supra note II, at 153 .

${ }^{35}$ Ohio H. B. No. 253 , r94 $\mathrm{r}$, would exempt the first $\$ 25$ of the purchase price paid for clothing or shoes.

${ }^{36}$ Ala. Gen. Acts I939, act No. I8, §5(c); ARK. Drg. Stat. (Pope, 1937) §I4082(b); Colo. StAT. ANN. (Michie, 1935) c. $144, \$ 15$ (where the special tax exceeds $121 / 2 \%$ of sales price); Iows Code (Reichmann, 1939) \$6943.077 ("blanket" provision); Kan. GEN. STAT. ANN. (Corrick, Supp. 1939) \$79.3606 (a); Oho Gen. Code Ann. (Page, 1937) §5546-2(5); Okla. Laws 1937, c. 66, art. I1, §6(a); S. D. Code (1939) $\$ 57.3202(6)$; Utah Laws r933, c. 63, \$6 ("blanket" provision).
} 
other tobacco products, ${ }^{37}$ malt, ${ }^{38}$ amusements, ${ }^{39}$ motor vehicles, ${ }^{40}$ and other products and services which are specially taxed. Several states have blanket exemptions of sales otherwise taxable, either by the home state or by another state. ${ }^{41}$ Since these exemptions operate pro tanto, the buyer is excused from paying the entire general sales or use tax only when it is less than the other consumption tax; if the latter tax is less, the buyer must pay the difference between the two. Arkansas does not confine the credit to cases in which the other tax is a consumption tax but permits a deduction for that "portion of all retail sales on articles and/or commodities on which a State privilege tax or license is already collected."42 The most common exemption, that of gasoline and other motor fuel, which appears in the acts of I9 states, ${ }^{43}$ bears closer scrutiny. Originally, all funds from gasoline taxes were intended to be used for construction and maintenance of highways and roads; to a great extent they are still used for such purposes. In the states which exempt sales of gasoline and other motor fuel from the general sales tax, approximately 90 per cent of the funds derived from the special gasoline tax is allocated to the use of the highway departments. In short, these taxpayers are really paying for a special service, the building and upkeep of the roads. On the other hand, the funds from the general consumption taxes are not used for the particular benefit of any one class of taxpayers. It is evident, then, that this large revenue-reducing exemption, instead of short-circuiting an unfair discrimination against gasoline expenditures, unwisely prevents this commodity from bearing its just portion of the general tax burden. At least, it should be subjected to the retail sales taxes to the extent that the gasoline is purchased for consumption. ${ }^{44}$

${ }^{37}$ Ala. Gen. Acts I939, act No. I8, \$5(I); ARr. Dic. StAт. (Pope, I937) §14082(b) (blanket provision); Colo. StAt. ANN. (Michie, 1935) c. 144 , $\$ 15$ (where special tax exceeds $121 / 4 \%$ of sales price); Iowa Code (Reichmann, I939) \$6943.077 (blanket provision); Kan. Gen. Stat. AnN. (Corrick, Supp. 1939) \$79-3606(a); Mrss. Code ANn. (Supp. I938) \$2326; Orno Gen. Code ANN. (Page, I937) \$55462(4); Okla. Laws I937, c. 66, art. II, $\$ 6($ b); S. D. CoDE (I939) §57.3202(6); Utah Laws I933, c. 63, \$6 (blanket provision).

${ }^{38}$ See statutes collected in note 36 , supra.

${ }^{30}$ Colo. Stat. Ans. (Michie, I935) c. I44, $\$ 15^{\prime}$ (blanket provision); Miss. Code AnN. (Supp. r938) $\$ 2326$.

${ }^{6}$ Iowa CoDE (Reichmann, 1939) \$6943.ro8; N. D. Laws 1939, c. $24 x, \S 3(2)$ (use tax exemption); Okla. Laws 1939, c. 66, art. II, $\$ 6(\mathrm{D})$; S. D. Laws I939, c. $276, \$ 4(2)$ (use tax exemption); W. VA. CODE ANN. (Michie \& Sublett, r937) $9999(9) 5$.

${ }^{\$ 1}$ Iowa Code (Reichmann, I939) \$6943.077; Kan. Gen. Stat. Ann. (Corrick, Supp. 1939) \$79-3705 (use tax exemption); Mich. CoMp. Laws (Mason, Supp. 1940) $\$ 3663-44$ (f) (use tax exemption).

12 ARK. Dig. Stat. (Pope, I937) $\$ 14082$ (b). Tax avoidance possibilities in such a provision appeared in Wiseman v. Madison Cadillac Co., rgr Ark. ro2x, 88 S. W. (2d) ro07 (r935), when the buyer of an automobile tried to credit against the sales tax thereon, the fee which he had paid for permission to drive the car. But the court held that this was a tax on the privilege of using the roads, and, the tax not being on a commodity, that the claim for the exemption was ill-founded.

${ }^{13}$ Ala. Gen. Acts 1939, act No. I8, §5(c); Ariz. Code AnN. (1939) §73-1329; Ark. Dig. Stat. (Pope, 1937) §14082(b); CaL. GEN. Laws (Decring, 1937) act 8493, §6; Colo. Stat. Ann. (Michie, I935) c. I44, \$15; Jown Code (Reichmann, I939) \$6943.077; Kan. Gen. Stat. AnN. (Corrick, Supp. r939) \$793606(a); Miss. Code Ann. (Supp. 1938) \$2326; Mo. Rev. Stat. AnN. (I939) \$II409; N. M. Stat. ANN. (Courtright, Supp. I938) §I4I-I7I6(i); N. C. Code ANN. (Michie, I939) \$7880(156)f(b); N. D. Laws 1937 , c. 249, \$4; OHro Gen. Cone ANn. (Page, I937) \$5546-2(3); Okla. Laws I939, c. 66, art. II, $\$ 6(\mathrm{I})$; S. D. Code (1939) \$57.3202(6); Utah Laws I933, c. 63, §6; WASH. Rev. Stat. ANN. (Remington, Supp. r940) \$8370-rg(e); W. VA. CoDE ANN. (Michie \& Sublett, r937) §999(9)r; Wyo. Laws 1937 , c. $102, \$ 6$.

"For a good discussion of this general problem, see JACOBY, op. cit. supra note II, at I08 et seq.; and see Smart and Hart, The Distribution of Reventses from State-Collected Consumer Taxes, supra this issue. 
Avoidance of multiple taxation of the vertical type is illustrated by the exclusion, adopted by practically every state, of sales to manufacturers and producers of tangible personal property which "enters into and becomes an ingredient or component part of tangible personal property to be ultimately sold at retail." As a sheer matter of legislative nomenclature, this is not an exemption but is a part of the definition of a wholesale sale, not reached by retail sales taxes; as a matter of economics, it is an exemption, for it saves the sale of ingredient commodities from the tax, while the sale of non-ingredient commodities, which also contribute to the cost that the consumer must pay for the finished product, is taxed.

The operation of this exemption can best be shown by a simple example: $A$ manufacturer of cotton clothing buys cotton, an office desk, and a cutting machine. ${ }^{45}$ In every state which has the physical ingredient rule, the sale of the cotton is exempt, since it becomes an integral part of the ultimate product. In every state except Michigan, Ohio and West Virginia, the sale of the machine would be taxed as a noningredient. And, with the exception of West Virginia, every state taxes the sale of the office desk for the same reason. ${ }^{48}$

There seems to be no sensible reason for this distinction, for obviously, the cost of the machine and desk enters into the price of the manufactured product as much as does the cost of the cotton. ${ }^{47}$ If an aversion to pyramiding motivates the exemption of physical ingredients, then the sales of all articles whose costs enter into the cost of the ultimate goods, should be exempt. ${ }^{48}$ Unwarranted though it is, the distinction is superficially hidden by the legislative declarations that the sale of an ingredient is a sale for resale, and hence not taxable, whereas the sale of a non-ingredient is a sale for consumption, since this commodity, "shall never again enter trade channels as an article of merchandise." Whether or not a sale to a manufacturer or producer is in the economic sense a sale for consumption, it is clear that the use of the concept

${ }^{45}$ Essentially the same facts are presented in Bedford v. Colorado Fuel \& Iron Corp., 102 Colo. $53^{8}$, $8 \mathrm{I}$ P. (2d) 752 ( 1938 ), in which the court construed "enters into the processing of" as "bccomes an ingredient."

${ }^{40}$ Michigan defines a retail sale as any sale for consumption other than for "consumption or use in industrial processing. . . ." Mrch. CoMp. LAws (Mason, Supp. 1940) \$3663-r(b). Ohio's definition of retail sale is any sale other than a sale in which the purpose is to incorporate the article, or "to use or consume the thing transferred directly in the production of . . ." property to be sold at rctail. OHro GeN. Code ANN. (Page, I937) \$5546-x. West Virginia defines a wholesale dealer as one who sells "machinery, supplies and materials ... to persons engaged in manfacturing. ..."W. VA. ConE ANN. (Michie \& Sublett, 1937) $\$ 999(2) 7$.

${ }^{\star 7}$ In State Board of Equalization v. Oil Wells Supply Co., $5 x$ Wyo. 226, 65 P. (2d) 1093 (1937), and State Board of Equalization v. Stanolind Oil \& Gas Co., 51 Wyo. 237, 65 P. (2d) 1095 (1937), the court granted the exemption to sales of commodities which were not ingredients, under a statute excepting sales of an article "which is actually used in the production of, . . . or becomes an ingredient." "The legislature then amended the statute, so as to exempt only ingredients.

${ }_{48}$ This argument was successfully used in State Tax Comm. v. Burns, $236 \mathrm{Ala} .307,182$ So. 1 (1938). The court allowed the sale of food to a restaurateur, prepared for customers but eaten by employecs, to go tax-free, on the ground that the cost of such food entered into the cost of cmployees' service, which in turn entered into the cost of the food upon which the customer paid a sales tax. The court said: "Those articles are constructively a part of that which is sold, and enhances its value on the basis of which the sales tax is paid." On rehearing, the court denied that its opinion conflicted with the physical ingredicnt rule, saying that the food had been purchased with intent to resell and not to consume. The physical ingredient rule in Alabama has since been repealed. Cf. Lone Star Cement Corp. v. State Tax Comm., 234 Ala. 465, x75 So. 399 (x937); Warren v. Fink, 146 Kan. 7x6, 72 P. (2d) 968 (1937). 
of consumption to confine the exemption to sales of articles which become constituents of the finished product is economically indefensible in view of the purpose behind the physical ingredient rule. The mere fact of ingrediency is certainly unrelated to a desire to escape pyramiding. ${ }^{49}$

In most states many questions of construction of this exemption are obviated by the requirement that the article, for its sale to be exempt, must become a component part of the manufactured or produced commodity. ${ }^{50}$ The Ohio provision, however, presents a difficulty of interpretation, since in addition to the sales of the commodities actually incorporated ${ }^{51}$ it exempts also the sales of those articles "consumed or used directly" in the process of production. In those states where feed is deemed to become a component part of livestock, ${ }^{52}$ there is the administrative difficulty of determining whether the livestock is to be sold, consumed personally by the producer, or both; for if it is consumed by the producer, the sale of the feed is taxable. And if the livestock is consumed in part and sold in part, administrators are presented with a difficult problem of allocation, one which is also raised by the physical ingredient rule and the exemption of sales of electricity, gas, and coal to be used in rendering taxable services. ${ }^{53}$

\section{Political Considerations}

Exemptions whose origins suggest the pressure of private interests reduce revenues without mitigating any unfair consequences of the taxes, while the reasons advanced for them range from the honest but invalid to the deliberately spurious.

The exemption of the purchase of mill machinery in five states, ${ }^{54}$ for example, is predicated on the necessity for attracting new industries to the state and for keeping local industries from moving to neighboring states. But there is evidence, confirmed by the experience of the majority of the states which have not found the insertion of this exemption necessary, that taxation is not one of the eleven motives which

${ }^{\circ}$ The physical ingredient rule as a technique for defining retail sale is discussed at length by Wahrhaftig, Meaning of Retail Sale and Storage, Use or Other Consumption, supra this issue.

${ }^{50} \mathrm{~A}$ sale of fertilizer is not exempt, as entering into the processing of crops. Kennedy v. State Board, 224 Iowa $405,276 \mathrm{~N}$. W. 205 (1937). A sale of rubber heels to a shoe repairer is exempt. Revzan v. Nudleman, 370 Ill. I80, x8 N. E. (2d) 635 (1938). But see W. J. Sandberg Co. v. State Board, 225 Iowa 103, 278 N. W. 643 ( 1938 ), in which the court distinguishes between rubber heels and leather used in repairing shoes. A sale of parts of watches to a watch repairer is exempt. Marshall Co. v. Ames, 373 IIl. $38 \mathrm{r}, 26$ N. E. (2d) 483 (r940).

E1 Broadly, the Ohio test of direct use is whether the commodity is used in the production room or elsewhere. See JAсовY, op. cit. stepra note II, at 132, n. 38; I Op. Ofno Atr'y Gen. (1935) 422, Op. No. $4 \mathrm{I} 49$.

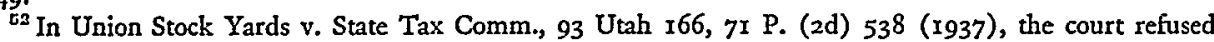
to read in an exemption of the sale of feed, as being a component part of livestock.

${ }^{63}$ Administrators realize the near futility of trying to make such an allocation. The Kansas revenue office seeks to go no further than to determine whether the dominant intent of the buyer is to resell or to consume. Kan. Reg. and Rulings (1940) art. 9(d). Compare State Tax Comm. v. Burns, supra note 48. For a judicial treatment of the problem of allocation, see Smith Oil Co. v. Dep't of Finance, 371 Ill. 405,21 N. E. (2d) 292 (I939).

${ }^{5}$ Ala. Gen. Acts 1939 , act No. $18, \S 5$ (r), expressly exempts mill machinery. N.C. Code ANN. (Michie, 1939) $\$ 7880$ ( 156$) f(m)$, expressly exempts mill machinery as a wholesale sale. Mich. CoMp. LAws (Mason, Supp. 1940) $\$ 3663-\mathrm{I}(\mathrm{b})$, excludes from the definition of retail those articles which are "used in industrial processing." N. D. Laws 1939, c. $24 \mathrm{I}, \$ 3(8)$, and S. D. Laws 1939, c. $276, \$ 4$, exempt only from the use tax "products used in manufacturing." 
induce industries to move. ${ }^{55}$ Nor is the avoidance of multiple vertical taxation a satisfactory justification for this exemption, since no effort is made to relieve from taxation other non-ingredient purchases made by mills. The rather bold argument of the manufacturers in Boyer-Campbell Co. v. Fry ${ }^{56}$ that the sale of mill machinery should be excluded from the definition of sale at retail mainly because the tax would cause "irreparable injury to business interests" in the state was fortunately unavailing, although the private interests later carried their contention successfully to the legislature. ${ }^{.57}$

The very frequent exemption of the sale of newspapers ${ }^{58}$ may be sustained because of the difficulty of taxing the consumer on three-cent or five-cent purchases and the unfairness of requiring the seller to bear the burden by remitting a designated percentage of gross receipts. But the exemptions of the sales of magazines ${ }^{60}$ and religious publications, ${ }^{60}$ newsprint, ${ }^{61}$ and advertising ${ }^{02}$ are not defensible. They are said to encourage the publication of information and the distribution of literature; but newspapers and magazines are not exempted from income, property, and other forms of state taxation which are now, significantly enough, past condemnation in the public press, while the sale of paper for books, less likely vehicles for the circulation of adverse comment on sales taxes and legislators, is not exempt from sales tax statutes.

The prevention of repeated taxation on the same article has been advanced as a reason for exempting the sale of used property, especially used automobiles. ${ }^{03} \mathrm{~A}$ consumer tax, however, is a tax measured by consumer outlay, so that there is in this attempted justification the same confusion between physical and economic burden which is apparent in the exemption of the sale of ingredients entering into the physical substance of other articles later to be sold. Taxpayers, if there is no exemption, pay a tax again and again on the sale of the same used car as it is turned in and re-sold. But "there is no limit," as the court pointed out in Bedford v. Hart$m a n,{ }^{64}$ in which it was contended unsuccessfully that the tax statute could not have

${ }^{\mathrm{E}}$ See findings of Civic Development Committee of the National Electric Light Association and the Policy Holders' Service Bureau of the Metropolitan Life Insurance Company commented on in Martin, stupra note $\mathrm{I}$, at 52 . 27 I Mich. 282,260 N. W. 165,98 A. L. R. 827 (1935).

${ }_{57}$ Mrch. Comp. Laws (Mason, Supp. 1940) $\$_{3} 663-\mathrm{x}(\mathrm{b})$.

${ }^{58}$ Ala. Gen. Acts 1939, act No. I8, \$5(j); Cal. Laws 1940, c. 46, \$2.5 (all publications); N. M. STsr. ANN. (Courtwright, Supp. I938) §I4I-I7I6(h); Otno Gen. Code ANN. (Page, 1937) \$5546-2(2b); Okla. Laws 1939, c. 66, §6(j); Wash. Rev. Stat. ANN. (Remington, Supp. r940) \$8370-19(c).

${ }^{89}$ N. M. Stat. ANn. (Courtwright, Supp. 1938) \$r41-1716(h); Oho Gen. Code ANN. (Page, 1937) $\$ 5546-2$ (2b) (subscriptions). Alabama exempted the sale of ". . . agricultural or religious publications and magazines," Ala. Gen. and Loc. Acts $1936-7$, act No. 126, \$4(x), until Long v. Paulos, 234 Ala. 149, I74 So. 230 (1937), interpreted the provision to include all magazines. The word "magazines" was dropped when, with changes, the statute was re-enacted. Ala. Gen. Acts 1939, act No. 18, $85(j)$.

${ }^{60}$ Ala. Gen. Acts 1939, act No. 18, \$5(j).

${ }^{62}$ Ibid.; CaL. Gen. Laws (Deering, Supp. 1939) act 8495a, $\$ 4$ (h) (use tax only); N. M. Laws I939, c. $95, \$ 4(\mathrm{j})$.

${ }_{62}$ Okla. Laws r939, c. 66, $\$ 6(\mathrm{p})$ (also advertising on billboards); Mrcr. Comp. Laws (Mason, Supp. I940) $\$ 3663-\mathrm{r}(\mathrm{c})$.

${ }^{63}$ Ala. Gen. Acts 1939, act No. 18, \$5(p); Iowa Code (Reichmann, 1939) \$6943.076(5); Kan. GeN. Stat. Ann. (Corrick, Supp. r939) \$79-3602(h); Mrch. Comp. Laws (Mason, Supp. 1940) \$3663-I(g); N. C. Code ANN. (Michie, 1939) \$7880(156)h; Colo. H. B. No. 355, 1941.

${ }_{64}$ ro4 Colo. 190, 194, 89 P. (2d) 584, 585-586 (1939). 
meant to tax the sale of a used car, "to the number of times a particular article of merchandise may be subject to a sales tax so long as it remains in the stream of commerce and goes through the regular channels of trade ..." This form of repeated taxation, which is neither a multiple or pyramided taxation, is objectionable only to automobile dealers, for whom the disposal of second-hand automobiles is a major problem. Not only will the court not find a used-property exemption where none is expressed; in North Carolina at least, it has been unfriendly to one which existed. The exemption of "used articles taken as part payment on the sale of new articles" was held, in McCanless Motor Co. v. Maxwell, ${ }^{65}$ not to exempt the sale of used articles taken in part payment for other used articles. ${ }^{66}$

The exemption of fertilizer, ${ }^{67}$ agricultural containers,${ }^{68}$ and non-ingredient feeds and seeds, ${ }^{69}$ all purchased chiefly by farmers, is an exemption found in many states. Although it results in certain mitigative consequences if the farmer-buyer happens to be poor, it is traceable more directly to the hand of agricultural blocs in state legislatures.

Outright subsidy, motivated either by a consideration of the importance of the industry to the economic well-being of the state, or by pressure brought to bear by that industry, or both, is the net effect of the exemption of ice in North Carolina and Ohio, ${ }^{70}$ explosives in Ohio, ${ }^{71}$ minerals in Utah, ${ }^{72}$ cotton and cotton seed in Arkansas and Mississippi, ${ }^{73}$ gold and silver in California, ${ }^{74}$ agricultural limestone in Iowa, ${ }^{75}$ railroad equipment in Alabama and New Mexico, ${ }^{76}$ and vessels of more than a specified weight in Alabama, California, Michigan, and Ohio. ${ }^{77}$

A very large number of states exempt the sales by utilities of transportation services, and of electricity, steam, gas, fuel, and water when made to consumers through

${ }^{o s} 2$ ro N. C. 725,188 S. E. 389 (1936).

${ }^{\circ 0}$ Ratchford, The Measure of Consumption Taxes, supra this issue, discusses the problem of trade-ins from the point of view of measurement of the tax base.

${ }^{\circ 7}$ Ala. Gen. Acts 1939, act No. 18 , $\$ 5$ (g); Towa Code (Reichmann, 1939) \$6943.074(3); Miss. Code Ans. (Supp. 1938) $\$ 2328(\mathrm{~m})$; N. M. Laws 1939, c. $95, \S 4(\mathrm{~h})$ (use tax); Wyo. Laws 1937, c. 102, $\$ 2(\mathrm{f})$. Mississippi taxes manufacturers on the value of the goods manufactured as determined by gross proceeds of sale, whereas retailers are taxed directly on their gross proceeds. Mrss. Cope Ann. (Supp. I938) $\$ \$ 2319$, 2320. The exemption of the sale of fertilizer and agricultural containers under this joint tax does not entitle manufacturers to deduct proceeds from fertilizer sales, Jackson Fertilizer Co. v. Stone, I73 Miss. I83, I62 So. I7I (1935), or from sales of agricultural containers. Southern Package Corp v. State, I74 Miss. 212,164 So. 45 (1935).

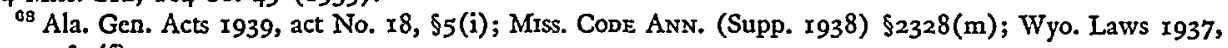
c. I02, $\$ 2(f)$.

${ }^{00}$ Ala. Gen. Acts I939, act No. I8, $\$ 5(\mathrm{~h})$; Miss. Code ANn. (Supp. I938) $\$ 2328(\mathrm{~m})$; N. M. Laws 1939, c. 95, $\$ 4$ (h) (use tax); Oho Gen. Code ANn. (Page, 1937) \$5546-2(2a); Wyo. Laws I937, C. I02, $\S_{2}(f)$.

${ }^{70}$ N. C. Code ANn. (Michie, I939) \$7880(156)j; Ohro Gen. Code AnN. (Page, I937) \$5546-2(2c).

71 OHo Gen. Code ANn. (Page, 1937) \$5546-2(II). ${ }^{72}$ Utah Laws r937, c. II4, $\$ 4$ (c).

${ }^{73}$ ARr. Dig. Stat. (Pope, 1937) \$1407I; Miss. Code ANN. (Supp. r938) \$2328(i).

${ }^{7}$ Cat. Gen. Laws (Deering, Supp. I939) act $8493, \$ 5$ (c), $\$ 5.14$. Since most gold is sold to the United States, the sale of gold is almost completely exempt under the exemption in most states of sales to the Federal Government. Luke v. East Vulture Mining Co., 47 Ariz. 220, 54 P. (2d) x002 (1936).

${ }^{75}$ Iowa Code (Reichmann, 1939) $\$ 6943.074(3)$.

${ }^{70}$ Ala. Gen. Acts 1939, act No. 18, \$5(n); N. M. Laws r939, c. 95, \$4(r).

${ }_{77}$ Ala. Gen. Acts 1939, act No. 18, \$5(n); CAL. GeN. LAws (Deering, r937) act 8493, \$5.7; Mrch. CoMp. Laws (Mason, Supp. I940) \$3663-I(d); OHo GEN. Code ANN. (Page, r937) \$5546-2(I3) (and dirigibles). 
mains and pipes. ${ }^{78}$ These exemptions, when not related to the avoidance of double taxation, the operation of the physical ingredient rule, or the exemption of necessaries, are probably attributable to the efforts of the public utilities in convincing legislators that gas, electricity, or bus rides are really not the sort of tangible personal property which should be included in the scope of the tax. But where there is no exemption there is certainly no reason for reading one in, either as to all utilities, as the court did in Peoples Gas Light Co. v. Ames, ${ }^{70}$ or as to municipally-owned utilities, as the courts did in Wyandotte v. State Board ${ }^{80}$ and City of Webster Groves v. Smith. ${ }^{81}$

One view of the policy of the use tax itself is to protect home industry by taxing purchasers on the use of commodities purchased outside the state, in order to discourage them from attempting to avoid the state sales tax. If the purchases, however, could not ordinarily have been made within the state, so that the out-state purchase was really no attempt to avoid the sales tax, there would be no reason for assessing a use tax; and this seems to have been the purpose behind the exemption in practically all states of commodities "not readily obtainable" or "not promptly purchaseable" in the state. ${ }^{82}$ But if, under another view, the use tax is intended less to protect home industry from neighboring non-sales-tax states than it is to catch interstate sales not constitutionally taxable as sales, the not-readily-obtainable exemption has no relation to the purposes of the act. Inasmuch as the very enactment of the exemption would seem to imply that the legislature had adopted the former policy, ${ }^{83}$ a case like Continental Supply Co. v. People, ${ }^{84}$ in which the court declined

${ }^{78}$ Ala. Gen. Acts 1939, acts No. r8, $\$ 5(q)$, and $67, \$ 3(q)$; CAL. Gen. Laws (Deering, Supp. 1939) act $8493, \S 5(\mathrm{~b})$; Iowa Code (Reichmann, r939) $\$ 6493.076(2)$; Mich. Comp. Laws (Mason, Supp. 1940) $\$ 3663-I(e) ; N$. M. Stat. ANn. (Courtwright, Supp. I938) \$I4I-I7I6(k); N. D. Laws 1937, c. 249, $\$ 3$ (b); Oho Gen. Stat. Ann. (Page, r937) \$5546-2(b); Okla. Laws r939, c. 66, $\$ 6(\mathrm{~g})$, (h), and (m); S. D. Code (1939) \$57.3202(2) and S. D. Laws 1939, c. 276, \$4(8); Utah Laws 2d Sp. Scss. 1933, c. 20, \$4(b)I; W. VA. CODE ANN. (Michic \& Sublett, Supp. 1939) \$999(9)2. Wyo. Laws 1937, c. 118, $\$ 4(\mathrm{f})$ and $(\mathrm{h})$, containing a similar exemption, has this year been amended to subject most public utility sales to taxation. Alone exempted are intracity cabs and buses charging less than 24 cents fare. Wyo. Laws $x 94$ I, c. 98.

${ }^{70} 359$ Ill. 152, 194 N. E. 260 (1934). The court held that there was no retail sale of tangible personal property.

${ }^{80} 278$ Mich. $47,54,270$ N. W. $2 r_{1}, 2 r_{3}$ (1936). The court said that "the well-established rule of exemption of municipal property from general taxation should carry over to the sales tax."

${ }^{81} 340$ Mo. 798,102 S. W. (2d) 618 (1937).

82 Miss. Code Ans. (Supp. 1938) $\$ 2358(d) ;$ S. D. Laws r939, c. 276, $\$ 4(6)$ and (9); Wyo. Rev. STAT. (Supp. 1940) \$115-2604(k); see JACOBY, op. cit. stipra note II, at I5I-I54. Iowa Code (Reichmann, 1939) $\$ 6493.104(5)$ exempts property "not readily obtainable in Iowa and used in the operation of street railways." Here the readily-obtainable rule must have been adopted at the behest of private interests and modified so as to apply only to purchases made by them.

${ }^{83}$ In Pacific Tel. and Tel. v. Henneford, 195 Wash. 553, 560, 8I P. (2d) 786, 790 (1938), the court read in a readily-purchasable exemption and freed from taxation the purchase of telephone equipment outside the state. "The legislature," said the court, "by the title given to the statute declared that the tax was a compensating tax, which manifestly evinces neither purpose nor intention to tax non-competitor purchases which must be made outside this state." The following year, in City of Spokane v. State, 198 Wash. $682,686,89$ P. (2d) 826,828 (r939), the state came armed with the affidavits of lcgislators that the purpose of the act was to "compensate . . . for . . . loss of revenue resulting from the fact that the retail sales tax . . could not be lawfully collected from Washington purchasers with respect to interstate sales." The affidavits were inadmissible, but the court overruled its earlier decision and refused to exempt waterworks property not purchasable in, and actually secured outside the statc.

${ }^{84}{ }_{54}$ Wyo. 185,88 P. (2d) 488 (x939). 
to extend the exemption to the purchase of oil drills from out of the state, the seller's agent within the state not having had the drills in stock on demand, ${ }^{85}$ constitutes an unwarranted judicial adoption of the contrary policy. ${ }^{86}$

The administrative difficulties arising out of confusion in policy and the possibility of argument in each fact situation over the meaning of "readily obtainable," have caused the Deputy Director of Taxation in South Dakota to remark that this exemption is "the worst trouble-maker that the writer has ever confronted in tax administration." The mere mention of patents, trade names, quality of goods desired, or quantity of goods ordered, serves to indicate some of the pitfalls in an attempted definition of what goods may be considered readily obtainable or promptly purchasable in a state. $^{87}$

\section{Selective Sales and Use TAXes}

The considerations which underlie exemptions from general sales and use taxes will already have been weighed in the pre-natal stages of the selective sales or use tax act. Delimitation of the taxable class to selected subjects, while it will not obviate exemptions that go to the type of consumer, ${ }^{88}$ will necessarily remove in large part, if not entirely, the basis for commodity and transaction exclusions. Thus there are, within the scope of this study, no exemptions from the tobacco or beverage taxes. The same is essentially true of gasoline and motor fuel taxes, although there exists the borderline allowance of a refund or credit for satisfactorily proven loss of motor fuel by fire, lightning, explosion, accident, etc. ${ }^{89}$ In other selective consumption taxes, however, are to be found exemptions predicated on commodity or transaction. A few states exempt from the prohibitive rates of their oleomargarine taxes the sales of oleomargarine when used in puff pastry shortening, salad and mayonnaise dressings, flavoring compounds, pharmaceutical preparations, and various oils and preservatives. ${ }^{90}$ Kentucky's luxury taxes carry certain exemptions of functional character. ${ }^{91}$ From the inclusive cosmetics tax, technically imposed upon receipt of these

\footnotetext{
85 "It may be, as argued by counsel," said the court, "that under the construction given it, the subdivision will have little or a very restricted meaning. But that is what the legislature probably intended, in view of the fact, as already stated, that the use tax was meant to complement the sales tax." Id. at 193,88 P. (2d) at 490 .

${ }^{30}$ Compare the evaluation of this exemption by Wahrhaftig, supra note 49 , who considers it in connection with the definition of use or other consumption.

${ }^{87}$ The exemption in Ohio of the sale of hearses to be used exclusively out of the state [OHo GEN. Stat. AnN. (Page, 1937) $\$ 5546-2$ (12)] is an attempt to foster a home industry not by protecting it from other states but by encouraging out-state purchasers to come in and buy. This attempt to secure an advantage over the sellers of other states, whether the state of the buyer or another state to which the buyer would go instead of Ohio, invites a dangerous type of interstate competition. If the state of the buyer has a sales and use tax, moreover, the result of the exemption is to divert the tax on the hearse from the sales state granting the exemption to the state in which the use will be taxed, an example of subsidy at its worst. The move to repeal this exemption is well advised. Ohio S. B. No. 277, 194x.

${ }^{8 B}$ Exemptions of this character are covered by Conlon, Express or Implied Exclusions from Consumption Excises-Types of Consumers, infra this issue.

${ }^{80}$ E.g., Colo. Stat. Ann. (Michie, 1935) c. $16, \S_{3} 8_{3}(a)$. This type of allowance is close to that for loss from shrinkage and evaporation, which is treated as a phase of measurement by Ratchford, The Measure of Consumption Taxes, supra note 66.

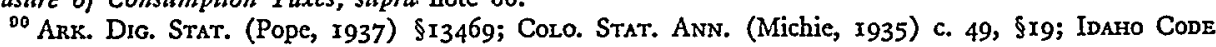
ANN. (I932) §36-I00I; UtAf Rev. Stat. ANN. (I933) §66-0-I.

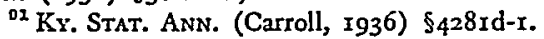


preparations in the state, ${ }^{92}$ there are excluded soaps retailing at 30 cents a pound or less and prescriptions written by physicians and filled by registered pharmacists. Similarly, the tax on sales of candy and certain confections excludes cakes, cookies and breads that are filled, coated or iced with "confections similar to candy."

The most important commodity or transaction exemptions to be found among selective consumption taxes are those appearing in the taxes on admissions. Admission taxation, whether based on single transactions or on gross receipts and whether restricted to particular types of amusement activity or inclusive of all forms of entertainment, is catholic enough to precipitate problems of policy which often find ultimate solution in terms of exemption provisions. Exempt minima in a handful of states ${ }^{\theta 3}$ testify to the existence here as with general consumption taxation of occasional concession to assumed administrative expediency. Apparently the Kentucky provision alone has precipitated litigation. Martin v. F. H. Bee Shows ${ }^{04}$ involved the applicability of the state's general ten-cent exemption minimum to a carnival separately charging that amount for admission and for each concession within the grounds. The fact that the concessions were run by independents appears to have bottomed the holding that no tax was due. Recently, the same court was called upon to determine, on the basis of the rates established above this general free minimum, the tax applicable on charges for athletic contests above a 50-cent exemption minimum. ${ }^{05}$

Ohio's taxation of athletic contests where the price of admission is $4 \mathrm{I}$ cents or more and the proceeds inure wholly or in part to the benefit of any high school or academy ${ }^{96}$ combines allowance of an exempt minimum with the far more common exemption of institutions and service groups. Where such exemption is granted, ${ }^{97}$ the statutory provisions attest variations in the extent of the political pressures successfully exerted. Almost invariably, educational, religious and charitable institutions are specified; but also favored here and there are such groups as civic organizations, American legion posts, national guard and other military associations, agricultural fairs, police and fire departments ${ }^{08}$ - and even Rooseveltian birthday balls. ${ }^{90}$ Usually, it is enough if the activity for which admission is charged is that

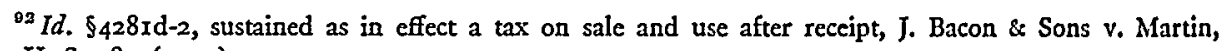
305 U. S. 380 (I939).

${ }^{03} \mathrm{KY}$. STAT. ANN. (Carroll, I936) $\$ 428 \mathrm{xf-4}$ (athletic contests), id. \$4281f-2, as amended Ky. Acts 1940, c. 181 (general); Mont. Laws 1937, c. 91, \$5 (general); Tex. Laws 3d Sess. 1936, c. 495, p. 2069 (motion pictures and other like amusements); WAst. REv. STAT. (Remington, Supp. 1940) \$8370-44 (general); W. VA. CoDE ANN. (Michie \& Sublett, Supp. 1939) \$96r (general; subdivision of general "privilege" tax on certain businesses).

of 27 K Ky. 822, Ir3 S. W. (2d) 448 (1938).

${ }^{95}$ Reeves v. Louisville Baseball Club, $283 \mathrm{Ky} .505,142$ S. W. (2d) I69 (1940).

${ }^{90}$ Ohio Gen. Code Ann. (Page, 1937) \$5544-3.

${ }^{97}$ No exemptions appear to be allowed in the admissions tax provisions of Ark. Acts 1935, art. 233; Me. Laws I939, c. 282; Mass. ANN. Laws (i933) c. I47, $\$ 40$ (exemption only if boxing match is an incidental feature); MrNN. Stat. (Mason, Supp. 1940) \$3260-5(3); N. J. Stat. ANN. (1939) 5: 2-12; Utah Laws 1933, c. 63, \$4(d); W. VA. Code ANN. (Michie \& Sublett, 1937) \$2833 (8); Wyo. Rev. Stat. (Courtright, Supp. I940) \$115-2506 (exempts only sales to religious, charitable and elecmosynary institutions; section in general sales tax act).

${ }^{08}$ See, e.g., the exemptions allowed by OHIO GeN. Code (Page, 1937) \$5544-3.

${ }^{\circ 9}$ S. C. Acts I940, No. x024. 
of one of the groups specified, ${ }^{100}$ or for its benefit. ${ }^{101}$ Occasionally, however, there appear, alone or in combination, the further limitations that the activity itself must be of the specified character, ${ }^{102}$ that no profit shall inure to any individual, ${ }^{103}$ or that the proceeds must go largely or entirely to the purposes indicated.104

"There appear to be very few cases involving the question whether admission charges to athletic contests or other types of receipts from extracurricular activities of schools or colleges are subject to taxation."105 The only recent decision seems to be State Tax Comm. $v$. Board of Education, ${ }^{106}$ where the exceptionally strict Kansas exemption ${ }^{107}$ was construed as not covering admissions to school dramatics, dances and athletic contests the proceeds from which were used to pay the costs involved. A forty-year-old North Carolina case, interpreting an "opera house tax" exemption of entertainments given for the sole benefit of religious, charitable or educational objects, held the tax inapplicable to conservatory concerts where any profit realized went toward new music and books. ${ }^{108}$ Statutory exemptions of other favored groups have enjoyed similar freedom from litigation. Again Kansas appears to have provided the lone recent case. State Tax Comm. v. State Board of Agriculture ${ }^{109}$ determined that the exemption of admissions to state and county fairs extended only to admission to the fair-grounds and was not intended to embrace admission to places of amusement and entertainment within the grounds. The probable explanation for the paucity of litigation over these exemptions lies in their similarity of wording to the much-litigated general property exemptions of like character.

${ }^{100}$ Ariz. Code ANn. (I939) \$73-1303(f) (general); Conn. STat. (1930) \$2204 (boxing and wrestling); Del. Rev. Code (I935) \$5509 (racing); FlA. CoMp. Laws (perm. supp.) §4I5I(77) (same); Ill. STat. AnN. (Jones, 1934) c. 5A, \$13 (same), id. c. 8, \$8 (boxing and wrestling); LA. Gen. Stat. ANn. (Dart. 1939) $\$ 8787.12$ (authorization of municipal general admission taxes); Mo. CoDE (Flack, I939) art. 56, $\S$ II7 (boxing and wrestling); Mrch. Comp. Laws (Mason, Supp. I940) $\$ 8859$ (ro) (same); Mo. REv. Stat. (I939) \$14605 (same), id. \$11453 (general); Monr. Rev. Code Ann. (Anderson \& McFarland, 1935) $\$ 4554$ (boxing), Mont. Laws 1937, c. 91, \$8 (general); N. Y. UNCoNsol. LAws \$220 (boxing and wrestling), id. \$1137 (racing); PA. Stat. ANN. (Purdon, Supp. 1940) tit. 4, \$23 (boxing and wrestling); Tex. Laws 3d Sess. r936, p. 2077 (general); VA. CODE ANN. (Michie \& Sublett, 1936) \$585(5I)(u) (boxing and wrestling); W. $\nabla_{A}$. CODE ANN. (Michie \& Sublett, I939) \$96r (general; subdivision of general "privilege" taxes on various classes of business); WIs. STAT. (I939) \$r6g.or(20)(a) (boxing). ${ }^{101}$ CAL. GeN. Laws (Deering, 1937) art. 6129, $\$ 7$ (boxing; cf. $\$ 13$, classifiable under note 10o, supra); OHIo GEN. CODE (Page, I937) \$5544-3(I) (general).

${ }^{102}$ Kan. Rev. Stat. (Corrick, Supp. 1939) $\$ 79-3603(\mathrm{e})$ (general; section in general sales tax act. See also note 104, infra).

${ }^{103} \mathrm{Ky}$. Stat. ANn. (Carroll, Supp. I940) $\$ 428 \mathrm{If}-2$ (general; see also note I04, infra); Miss. CODE ANN. (Supp. 1938) c. 75A, \$534 (general); S. C. Code (Michie, Supp. I936) \$253I (same); Wash. Rev. Stat. AnN. (Remington, Supp. I940) \$8370-49 (same).

104 Kan. Rev. Stat. (Corrick, Supp. 1939) \$79-3603(e) (general; section in general sales tax act); Kr. Stat. ANN. (Carroll, Supp. 1940) \$4281f-2 (general); N. C. CoDE (Michie, 1939) \$7880 (37) (plays and shows; tax applies even so unless local talent used); OHIo GeN. Cone (Page, x937) \$5544-3(2) (fairs); Wash. Rev. Stat. ANN. (Remington, Supp. 1940) $\$ 8276-16$ (athletic contests; proceeds must go primarily for benefit of members of groups exempted). ${ }_{105}$ Anno. (x938) Ix5 A. L. R. I4II.

200 x 46 Kan. 722, 73 P. (2d) 49 (1937). Friedman v. State, 242 App. Div. 3I4, 275 N. Y. Supp. 64 (1934), aff'd per curiam, 268 N. Y. 529,198 N. E. 388 (1935), concerned a very special situation of little or no general significance. ${ }_{107}$ See notes 102 and 104 , supra.

${ }^{108}$ Markham v. Southern Conservatory, I30 N. C. 276, 4I S. E. 53 I (I902).

${ }^{100}{ }_{4} 6 \mathrm{Kan}, 720,72$ P. (2d) 965 (1937). 